\title{
Complement C1q Antibody Measurement
}

National Cancer Institute

\section{Source}

National Cancer Institute. Complement C1q Antibody Measurement. NCI Thesaurus. Code C80173.

The determination of the amount of complement C1q antibody present in a sample. 